\title{
The Effect of the Contextual Teaching and Learning Model with the Encounter with God Learning Model Reviewing from Cognitive Styles on Learning Outcomes at Adiguna Maritim Indonesia Polytechnic Medan
}

\author{
Fatolosa Telaumbanua $^{1} \quad$ Maria Magdalena $^{2} \quad$ Albet Saragih $^{3}$ dan Wahyuputra Telaoembanoea ${ }^{4}$ \\ 1.Adiguna Maritime Polytechnic Indonesia \\ 2.STKIP Riama Medan \\ 3.North Sumatra Theological College Medan \\ 4.Institute of Teacher Training and Education, Gunung Sitoli
}

\begin{abstract}
Until now, the implementation of the Christian Religious Education lecture process at Non-Theological Colleges is well programmed according to the curriculum. However, especially Maritime higher education institutions that have graduated Ship Officers, both those who work in the country and those who work abroad, still stick to the negative image of society, namely "Evil Sailors Don't Fear God". Seeing and hearing this image, as a lecturer at the Adiguna Maritim Indonesia Polytechnic (Poltek Ami) Medan, who has served 33 years since 1986, as a child of God, a follower of Jesus Christ feels called and is interested and sympathetic, then seeks to find out how to overcome the impression this ugly from society. On the other hand, the researchers reviewed the learning model applied by the PAK course lecturers, who have been using the Contextual Teaching and Learning (CTL) learning model, with their learning styles and various teaching methods, from this the idea emerged to try to offer another learning model, namely the listed in the 2013 National Curriculum, the 2016 revision of the K13 year is the Encounter With God-EWG Learning Model, in terms of cognitive style. With all the knowledge that has been bestowed by God to the Servant, make a research with the title written above. The purpose of this research is to offers a Learning Model to strengthen students' faith in Jesus Christ in daily life and fear God and touch more on the affective aspect. The research carried out is experimental research by quantitative means and data analysis techniques using statistical formulations. It turns out that the PAK learning outcomes of students who use the EWG (Encounter With God) learning model with a score of 90, are higher than the learning outcomes obtained by students who use the EWG learning model using the CTL learning model, PAK learning outcomes with a score of 80 , and students who have a field independent cognitive style with a score of 85 , higher than the PAK learning outcomes of students who have a field dependent cognitive style with a score of 80 , and there is an interaction between the learning model and cognitive style significant impact on PAK learning outcomes, as well as the implication that the application of the EWG model is more motivated and It is fun to learn PAK and it is also supported by students who have a field independent cognitive style so that students feel as if they are EWG.

Keywords: CTL \& EWG Learning Model, Cognitive Style, Quantitative Research Experiments, Student Learning Outcomes

DOI: $10.7176 / \mathrm{JEP} / 12-21-05$

Publication date:July $31^{\text {st }} 2021$

\section{Introduction}

The implementation of Christian Religious Education in every educational institution functions to grow the attitudes and behavior of students in daily life based on Christian faith in order to form students as young generations who are responsible and can live side by side with followers of other religions in an atmosphere of mutual respect in accordance with Pancasila and the Law. the 1945 Constitution for the maintenance of national unity and integrity.

In presenting the material to students, including in general educational institutions, such as at Poltek Ami Medan, a learning model is chosen that can shape students' attitudes of steadfast faith in the Lord Jesus, and can be expressed in attitudes and actions. Indeed, there is an unfavorable image and impression from the public that maritime academic graduates who become sailors have bad behavior, as well as unsatisfactory learning outcomes.

As a Christian who does not dare to judge sailors and as a Lecturer at the Maritime Academy, as an educational institution that forms seafarers with the title ATT-III (Technical Expert Level III) as Engineer Officer, ANT-III (Level III Nautical Expert) as Deck Officer and A.Md (Intermediate Expert in Commercial Shipping and Ports), tries to minimize the gaps that occur, if possible, remove the bad impression from the public by starting in the task environment, by interviewing PAK Lecturers and seeing the use of learning models that have been using the CTL approach learning model and will try the Learning Model from the 2013/K13 National Curriculum, namely the Model Learning EWG and this is with the approval of the lecturer, and student learning styles, as well as linking elements of logic through cognitive style, knowledge possessed by students, and prioritizing the fear of
\end{abstract}


God. The word of the LORD says at Proverbs 1:7: "The fear of the LORD is the beginning of knowledge, but fools despise wisdom and discipline." It is hoped that the application of these three variables, learning models, cognitive styles will remain in a biblical frame, with the corridors of learning material underpinning the Bible. God's Word says 2 Timothy 3:16: "All writings which are inspired by God are beneficial for teaching, for reproofing error, for correcting conduct and for educating people in the truth."

\section{Research Method}

The population in this study were all Christian students for the 2018/2019 academic year, Poltek Ami - Medan which consisted of 3 study programs, namely: 1) Commercial and Port Shipping Administration Study Program (KPNK), 2) Engineering Study Program, and 3) Nautical Study Program. The total population is 102 people, so all the population becomes the object of this research. The total number of the study population can be seen in Table 1 below.

Table 1. List of Christian student population class 2018/2019 at Poltek Ami- Medan

\begin{tabular}{|c|c|c|}
\hline No & Study Program & Number of Students \\
\hline 1 & KPNK & $\mathbf{3 6}$ \\
\hline 2 & Teknika & $\mathbf{4 0}$ \\
\hline 3 & Nautika & $\mathbf{2 6}$ \\
\hline \multicolumn{2}{r|}{ Total } & $\mathbf{1 0 2}$ \\
\hline
\end{tabular}

Table 2. Distribution of Research Samples

\begin{tabular}{|r|c|c|}
\hline Study Program & Population & Number of Samples \\
\hline KPNK & 36 & 32 \\
\hline Teknika & 40 & 35 \\
\hline Nautika & 26 & 23 \\
\hline Total & $\mathbf{1 0 2}$ & $\mathbf{8 0}$ \\
\hline
\end{tabular}

The research implementation scheme can be seen in Fig.1. below.

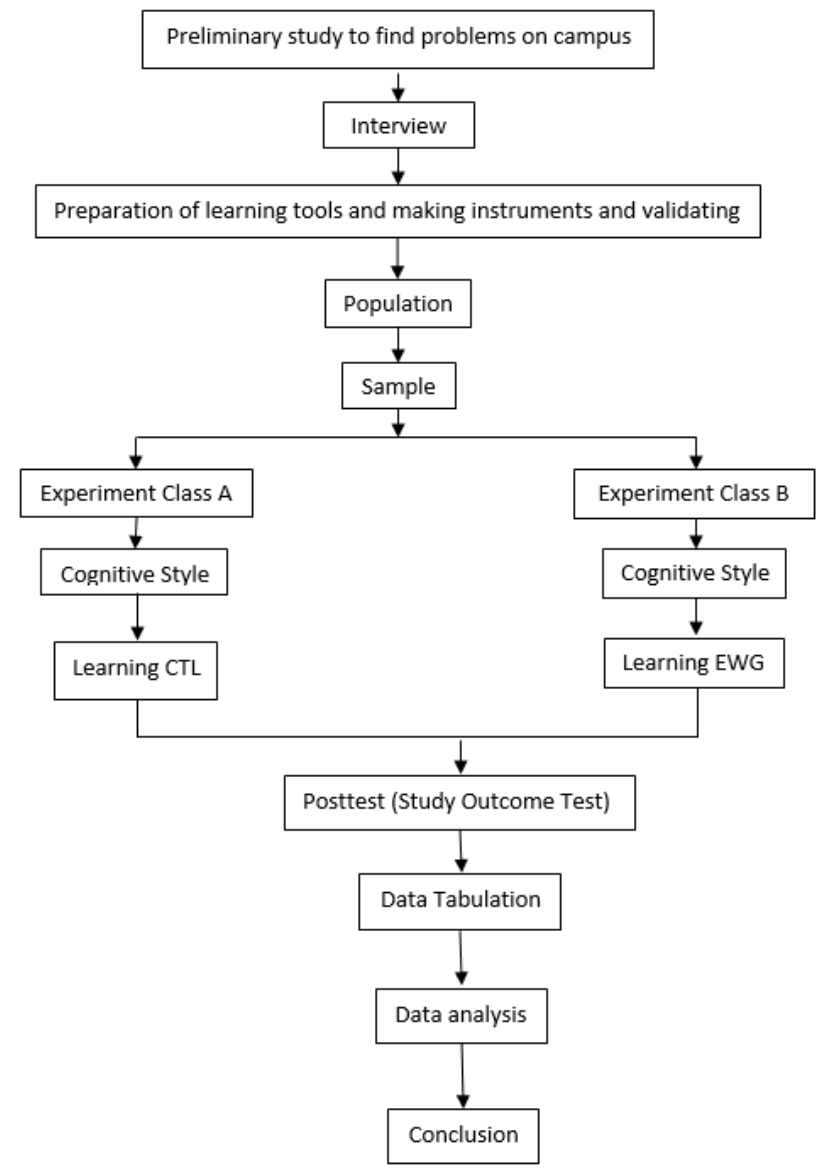

Fig. 1. Schematic of Research Implementation 


\section{Results and Discussion}

\section{Learning Outcomes in the EWG Learning Model Class}

Based on the scores of the learning outcomes variables with the EWG learning model that were collected, spread from the highest total score of 90 and the lowest 30, with Mode (Mo) =50; Median (Me) $=60 ;$ Mean $=61.03$. The frequency distribution of PAK learning outcomes in classes with the Encounter With God learning model can be seen in Table 3. below.

Table 3. Frequency Distribution of PAK learning outcomes in classes with the EWG learning model

\begin{tabular}{|c|c|c|c|}
\hline No. & Interval Class & Absolute Frequency & Relative Frequency (\%) \\
\hline 1 & $30-38$ & 4 & 2.94 \\
\hline 2 & $39-47$ & 4 & 5.88 \\
\hline 3 & $48-56$ & 12 & 35.29 \\
\hline 4 & $57-65$ & 9 & 20.59 \\
\hline 5 & $66-74$ & 3 & 17.65 \\
\hline 6 & $75-83$ & 2 & 14.71 \\
\hline 7 & $84-92$ & 1 & 2.94 \\
\hline & Amount & $\mathbf{3 4}$ & $\mathbf{1 0 0}$ \\
\hline
\end{tabular}

From Table 3. above shows that the learning outcomes of students who are taught with the EWG learning model are 15 people or $44,12 \%$ are below the average, 7 people or $20,59 \%$ are in the average class, and 12 people or $35.29 \%$ were above the average. The histogram can be seen in Fig. 2. below.

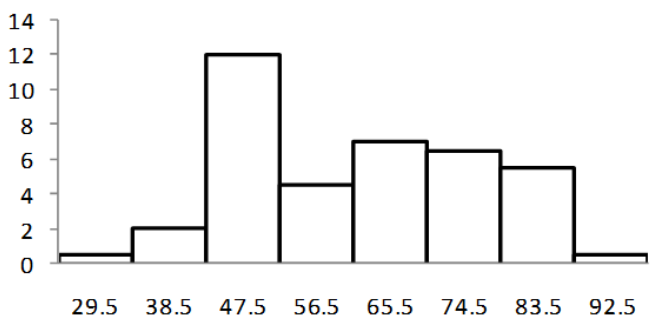

Fig. 2. Histogram of PAK Learning Outcomes in Classes With Encounter With God Learning Model

\section{Student PAK Learning Outcomes in CTL Model Classes}

Based on the score of the PAK learning outcomes variable in the class with the collected CTL learning model, spread from the highest total score of 80 and the lowest 40, with Mode $(\mathrm{Mo})=55$; Median $(\mathrm{Me})=55$; Mean $=56$, 47. The distribution of the frequency of PAK learning outcomes in classes with the CTL learning model can be seen in Table 4 below

Table 4. Frequency Distribution of PAK Learning Outcomes Scores in Classes with CTL learning models

\begin{tabular}{|c|c|c|c|}
\hline No. & Interval Class & Absolute Frequency & Relative Frequency (\%) \\
\hline 1 & $40-46$ & 4 & 11,76 \\
\hline 2 & $47-53$ & 4 & 11,76 \\
\hline 3 & $54-60$ & 12 & 35,29 \\
\hline 4 & $61-67$ & 9 & 26,47 \\
\hline 5 & $68-74$ & 3 & 8,82 \\
\hline 6 & $75-81$ & 2 & 5,88 \\
\hline \multicolumn{2}{|c|}{ Amount } & $\mathbf{3 4}$ & $\mathbf{1 0 0}$ \\
\hline
\end{tabular}

From Table 4. above shows that the learning outcomes of students who are taught with the CTL learning model are 8 people or $23.53 \%$ are below the average, 12 people or $35.29 \%$ are in the average class. , and 14 people or $41,18 \%$ were above the average. The histogram can be seen in Fig. 3.

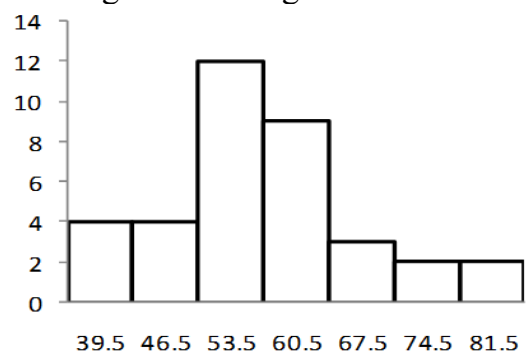

Fig. 3. Histogram of PAK Learning Outcomes Scores in Classes With Contextual Teaching and Learning Models 


\section{Learning Outcomes on Field Independent Cognitive Style}

Based on the scores of the PAK learning outcomes of students who have a field independent cognitive style collected, spread from the highest score of 90 and the lowest 45, with Mode $(\mathrm{Mo})=55$; Median $=65 ;(\mathrm{me})=63$, 57 ; Mean $=61,14$. The frequency distribution of PAK learning outcomes on field independent cognitive styles can be seen in Table 5 .

Table 5. Frequency Distribution of PAK Learning Outcomes Scores on Field Independent Cognitive Style

\begin{tabular}{|c|c|c|c|}
\hline No. & Interval Class & Absolute Frequency & Relative Frequency (\%) \\
\hline 1 & $45-52$ & 3 & 8.57 \\
\hline 2 & $53-60$ & 8 & 22.86 \\
\hline 3 & $61-68$ & 10 & 28.57 \\
\hline 4 & $69-76$ & 11 & 31.43 \\
\hline 5 & $77-84$ & 2 & 5.71 \\
\hline 6 & $85-92$ & 1 & 2.86 \\
\hline \multicolumn{2}{r|}{ Amount } & $\mathbf{3 5}$ & $\mathbf{1 0 0}$ \\
\hline
\end{tabular}

Table 5. above shows that the PAK learning outcomes of students who have a field independent cognitive style are 11 people or $31.43 \%$ below the average, 10 people or $28.57 \%$ are in the average class, and 14 people or $40.00 \%$ is above the average. Furthermore, it can be described by histogram the frequency distribution of PAK learning outcomes scores in the classroom on the field independent cognitive style as shown in Fig. 4.

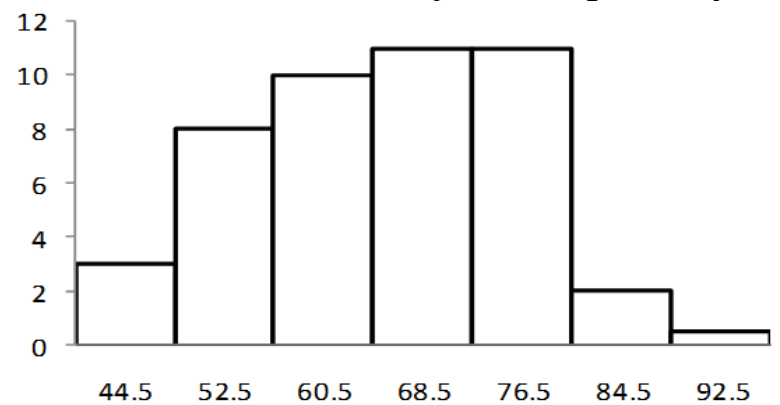

Fig. 4. Histogram of PAK Learning Outcomes Scores on Field Independent Cognitive Styles Students' PAK Learning Outcomes on Field Dependent Cognitive Styles

Based on the scores of the PAK learning outcomes of students who have a field dependent cognitive style collected, spread from the highest total score of 70 and the lowest 30, with Mode $(\mathrm{Mo})=50$; Median $(\mathrm{Me})=55$, Mean $=53.33$. The frequency distribution of PAK learning outcomes on the field dependent cognitive style can be seen in Table 6 .

Table 6. Frequency Distribution of PAK Learning Outcomes on Cognitive Style Field Dependent

\begin{tabular}{|c|c|c|c|}
\hline No. & Interval Class & Absolute Frequency & Relative Frequency (\%) \\
\hline 1 & $30-36$ & 2 & 6.06 \\
\hline 2 & $37-43$ & 2 & 6.0 .6 \\
\hline 3 & $44-50$ & 11 & 33.33 \\
\hline 4 & $51-57$ & 8 & 24.24 \\
\hline 5 & $58-64$ & 5 & 15.15 \\
\hline 6 & $67-71$ & 5 & 15.15 \\
\hline \multicolumn{2}{r}{ Amount } & $\mathbf{3 3}$ & $\mathbf{1 0 0}$ \\
\hline
\end{tabular}

From Table 6. above shows that the PAK learning outcomes of students who have a field dependent cognitive style are 15 people or $45,45 \%$ are below the average of 8 people or $24,24 \%$ are in the average class, and 10 people or $30,30 \%$ is above average. Histogram can be seen in Fig. 5.

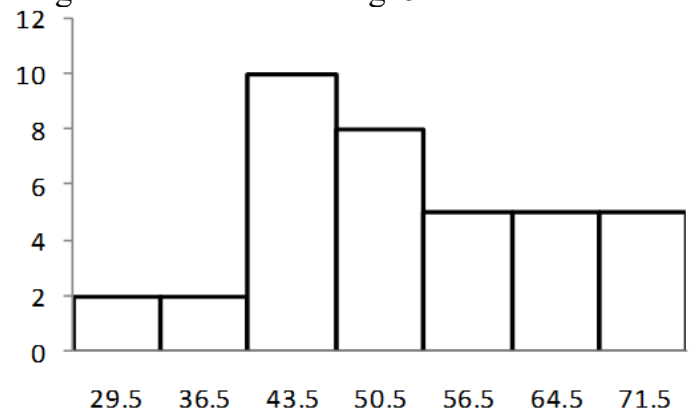

Fig. 5. Histogram of PAK Learning Outcomes on Cognitive Style field dependent 
Student PAK Learning Outcomes in Encounter With God Learning Model Class With Independent Field Cognitive Style

Based on the score of the PAK learning outcomes variable in the class with the Encounter With God learning model with field independent cognitive style collected, spread from the highest total score of 90 and the lowest 55, with Mode $(\mathrm{Mo})=70$ Median $(\mathrm{Me})=70 ;$ Mean $=70$. The distribution of the frequency of PAK learning outcomes in the class with the EWG learning model with field independent cognitive style can be seen in Table 7

Table 7. Frequency Distribution of PAK Learning Outcomes in Class with Encounter With God Learning Model with field independent cognitive style

\begin{tabular}{|c|c|c|c|}
\hline No. & Interval Class & Absolute Frequency & Relative Frequency (\%) \\
\hline 1 & $55-60$ & 2 & 11.76 \\
\hline 2 & $61-66$ & 3 & 17.65 \\
\hline 3 & $67-72$ & 6 & 35.29 \\
\hline 4 & $73-78$ & 4 & 23.53 \\
\hline 5 & $79-84$ & 1 & 5.88 \\
\hline 6 & $85-90$ & 1 & 5.88 \\
\hline & Amount & 17 & 100 \\
\hline
\end{tabular}

From Table 7 above shows that the learning outcomes of students who are taught with the EWG learning model with a field independent cognitive style style, namely 5 people or $29.41 \%$ are below the average, 60 people or $35.29 \%$ are in the average class, and 6 people or 35.295 are above the average. Histogram can be seen in Fig. 6.

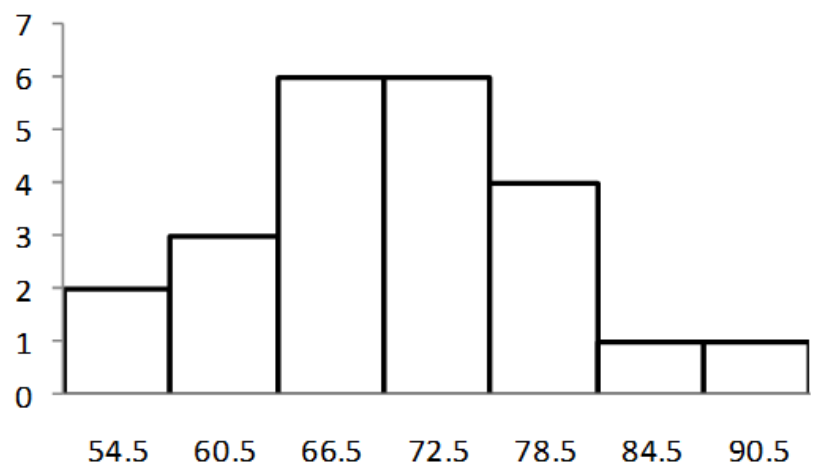

Fig. 6. Histogram of PAK learning outcomes in the classroom with the Encounter with God learning model with field independent cognitive style

Student PAK Learning Outcomes In Encounter With God Learning Model Class With Field Dependent Cognitive Style

Based on the variable scores of PAK learning outcomes of students in classes with the EWG learning model with field dependent cognitive style collected, spread from the highest total score of 70 and the lowest 30, with Mode $(\mathrm{Mo})=50 ;$ Median $(\mathrm{Me})=50 ;$ Mean $=51.76$. The distribution of PAK learning outcomes in the class with the EWG learning model with a field dependent cognitive style can be seen in Table 8.

Table. 8. Frequency Distribution of PAK Learning Outcomes Scores in Class With EWG Learning Model with field dependent cognitive style

\begin{tabular}{|c|c|c|c|}
\hline No. & Interval Class & Absolute Frequency & Relative Frequency (\%) \\
\hline 1 & $30-36$ & 1 & 5.88 \\
\hline 2 & $37-43$ & 2 & 11.76 \\
\hline 3 & $44-50$ & 5 & 29.41 \\
\hline 4 & $51-57$ & 5 & 29.41 \\
\hline 5 & $58-64$ & 3 & 17.65 \\
\hline 6 & $65-71$ & 1 & 5.88 \\
\hline \multicolumn{2}{r}{ Amount } & $\mathbf{1 7}$ & $\mathbf{1 0 0}$ \\
\hline
\end{tabular}

From table 8 , the above shows that the learning outcomes of students who are taught with the EWG learning model with a field dependent cognitive style are 8 people or $47,06 \%$ are below the average, 5 people or $29,41 \%$ are in the average class, and 4 people or $23,53 \%$ are above the average. Histogram can be seen in Fig. 7. 


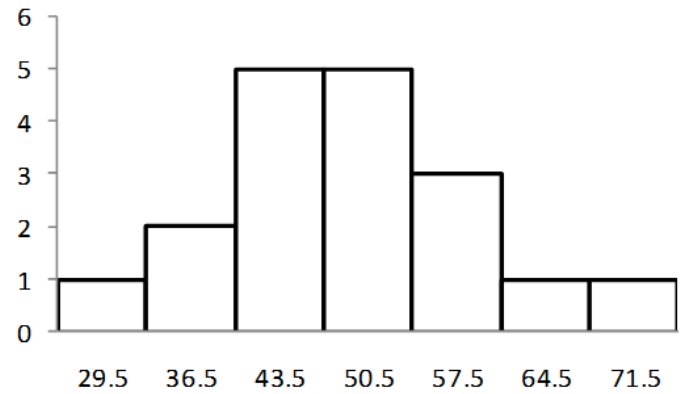

Fig. 7. Histogram of PAK learning outcomes in the classroom using the Encounter with God learning model with a field dependent cognitive style

PAK Learning Outcomes of Students in the Contextual Teaching and Learning Model Class with Field Independent Cognitive Style Contextual Teaching and Learning with Field Independent Cognitive Style Based on the scores of the PAK learning outcomes variables in the classroom using the contextual teaching and learning learning model with field independent cognitive style collected, spread from the highest total score of 85 and the lowest 50, with Mode $(\mathrm{Mo})=55$; Median $(\mathrm{Me})=55$; Mean $=57.50$. The distribution of the frequency of PAK learning outcomes in the classroom using the contextual teaching and learning model with field independent cognitive style can be seen in Table 9.

Table 9. Frequency Distribution of PAK Learning Outcomes Scores in Classes With Contextual Teaching and Learning Models with field independent cognitive style

\begin{tabular}{|c|c|c|c|}
\hline No. & Interval Class & Absolute Frequency & Relative Frequency (\%) \\
\hline 1 & $45-50$ & 1 & 5.56 \\
\hline 2 & $51-56$ & 3 & 16.67 \\
\hline 3 & $57-62$ & 5 & 27.78 \\
\hline 4 & $63-68$ & 5 & 27.78 \\
\hline 5 & $69-74$ & 2 & 11.11 \\
\hline 6 & $75-80$ & 2 & 11.11 \\
\hline \multicolumn{2}{r}{ Amount } & $\mathbf{1 8}$ & $\mathbf{1 0 0}$ \\
\hline
\end{tabular}

From Table 9, the above shows that the PAK learning outcomes of students who are taught using the CTL learning model with field independent cognitive style, namely 4 people or $22.22 \%$ are below the average of 5 people or $27,78 \%$ are in the average class. average, and 7 people or $50 \%$ were above the average. Histogram can be seen in Fig. 8 .

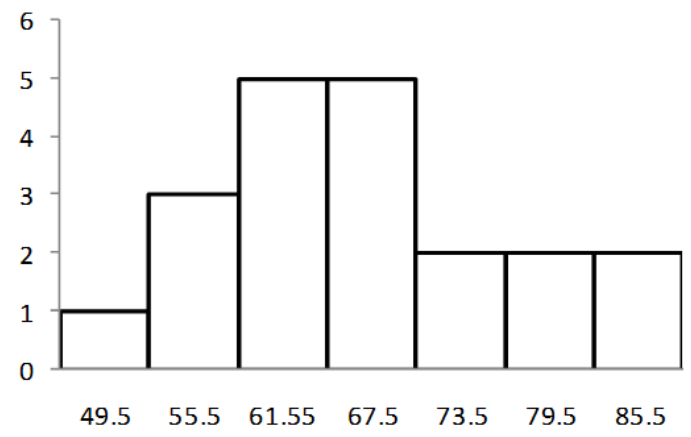

Fig. 8. PAK Learning Outcomes Scores in Classes with CTL Models with field independent cognitive style

PAK learning outcomes of students in the CTL Model Class with Field Dependent Cognitive Style

Based on the score of the PAK learning outcomes variable in the classroom with the CTL learning model with the field dependent cognitive style collected, spread out and the highest score is 70 and the lowest is 35, with Mode $(\mathrm{Mo})=60$ Median $(\mathrm{Me})=55$ Mean 55.31. The frequency distribution of PAK learning outcomes in classes with CTL learning models with field dependent cognitive style can be seen in Table 10. 
Table 10. Frequency Distribution of PAK learning outcomes scores in classes with CTL learning models with field dependent cognitive style

\begin{tabular}{|c|c|c|c|}
\hline No. & Interval Class & Absolute Frequency & Relative Frequency (\%) \\
\hline 1 & $35-40$ & 1 & 6.25 \\
\hline 2 & $41-46$ & 2 & 12.50 \\
\hline 3 & $47-52$ & 5 & 31.25 \\
\hline 4 & $53-58$ & 4 & 2500 \\
\hline 5 & $59-64$ & 2 & 12.50 \\
\hline 6 & $65-70$ & 2 & 12.50 \\
\hline & Amount & $\mathbf{1 6}$ & $\mathbf{1 0 0}$ \\
\hline
\end{tabular}

From Table 10, the above shows that the learning outcomes of students who are taught with the CTL learning model with a field dependent cognitive style, namely 8 people or $50 \%$ are below the average, 4 people or $25 \%$ are in the average class. and 4 people or $25 \%$ are above average. Furthermore, it can be described by histogram the frequency distribution of PAK learning outcomes in the classroom using the contextual teaching and learning model with a field dependent cognitive style as shown in Fig. 9.

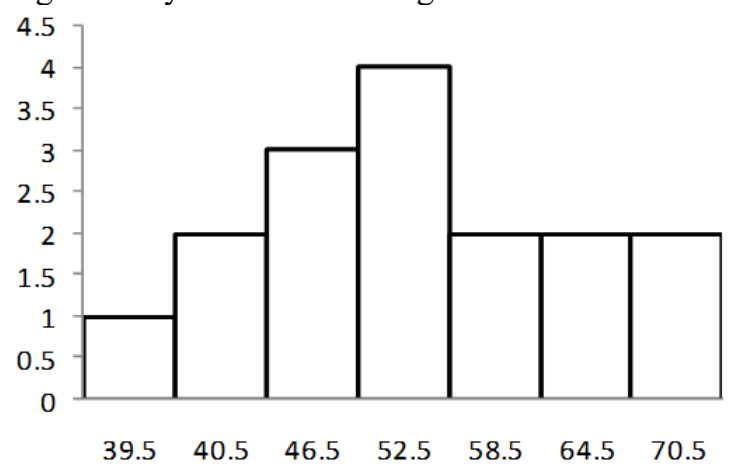

Fig. 9. Histogram of PAK learning outcomes in a classroom using a CTL model with a field dependent cognitive style

Based on the results of the study, it was found that the PAK learning outcomes in classes taught with the EWG learning model were higher than the PAK learning outcomes of students taught with the CTL learning model. This is because at the time of application in the room the steps in EWG learning namely Think time or thinking time provide opportunities for students about how to their opinions and answers independently before the question is answered by other students. In addition, lecturers can reduce the problem of having students chatting, because each student has a task to do on their own. plate time which is a refinement step from the previous steps, in the sense that this step helps all groups become more understanding about solving problems given based on the explanations of the other groups. So that students really understand when the lecturer gives corrections and fees at the end of the lecture.

These three activities cause students to go through three thinking processes, namely independently, in groups, and between groups. In addition, the number of group members consisting of only two people causes students to concentrate more in participating in learning activities so as to provide better learning outcomes, in the EWG learning model students work collaboratively to understand questions, share ideas, and formulate solutions to solve problems problem more effectively. EWG can influence and improve cognitive and affective thinking so that learning is better such as increased interaction, feedback, high motivation, and increased self-confidence, the EWG learning model provides a better influence among students. The activity of sharing the best answers with the class, sharing ideas in pairs makes students think independently about solving a learning topic. This model too improve cognitive and affective learning processes because students have more time to spend in discussions and selfreflection to better understand a lesson.

While the CTL learning model is a learning model that requires students to have good abilities in all things. This is because students directly absorb understanding from other groups. If students are less able to accept explanations from other students, the results are less than optimal. In addition, the discussion process will not last long due to limitations the time when students must visit each group. Especially for students who sometimes lack focus when being a visiting team. So that the essence of the material to be conveyed is not channeled properly. Whereas in PAK learning students must understand correctly what is the subject of the material presented, especially matters related to formulas so that they can relate them to events in everyday life.

From the description above, it can be seen that student learning outcomes related to the EWG learning model are more developed. Thus, it is clear that using the EWG learning model can have a better influence on PAK learning outcomes than CTL learning.

Cognitive style is the key to developing performance at work, at school, and in interpersonal situations 
(socializing with other people). According to Nurdin (2005) cognitive style is a thought process that combines how the mind receives the information in the brain.

Thinking is a process of drawing conclusions from understood problems which are then able to find solutions to those problems so as to produce new conclusions and findings. Each student has a different thinking style so that the specific level of understanding is also different. It should be remembered that students' cognitive style is not a student's ability, but is a way that students choose to use their thinking abilities. In this study, the cognitive style used is the field independent cognitive style and the field dependent cognitive style. To see the difference, groups of students who have a field independent cognitive style are united in the same group, and vice versa. Students who have an independent cognitive style get higher PAK learning outcomes than students who have a field dependent cognitive style. This is because students who have a field independent cognitive style tend to use the left hemisphere where the left brain's thinking process is scientific. Logical, critical, sequential, linear, and rational. In addition, independent field thinkers are experts in matters relating to facts, data and formulas.

So that it fits the PAK learning characteristics. This is in line with the opinion of Winkel (2004) which states that the left brain is more academic in nature and plays a role in processing logic, words, mathematics, and sequences. This is what causes learning outcomes with field independent cognitive style to get higher results. In addition, in this study, lecturers used various methods so that students with field independent cognitive style were more enthusiastic and enthusiastic about the ongoing learning activities.

The PAK experimental activities carried out can export new ideas and systems for students who have a field independent cognitive style. While the field dependent cognitive style is the dominant way of thinking using the right brain that is creative, not detailed and emotional.

In managing information, the thinking process is done by going through the steps in a procedure according to what he wants. Field dependent thinkers can start or do something in the middle or end by working backwards. So that students who have a field dependent cognitive style tend to be disorganized in doing a given task, especially those related to practicum. They often do not follow the procedures listed in the book so that the results they get are sometimes far from what they expected. In this case, it is concluded that the PAK learning outcomes of students who have a field independent cognitive style are higher than those of students who have a field dependent cognitive style.

Then, the results showed that there was a significant interaction between learning models and cognitive styles on PAK learning outcomes. When viewed from the average PAK learning outcomes in the EWG group of students, it is higher than the average learning outcomes of other student groups. This is due to the application of the EWG learning model in accordance with the characteristics possessed by students with field independent cognitive styles. Someone who has a field independent cognitive style tends to be able to do it systematically, step by step or regularly, if you pay close attention to something in detail, can work well within time limits and it is rather difficult to work with many people.

This is supported which states that field independent thinkers tend to be perfectionists who are detail-oriented and learn while doing. So that in accordance with the learning steps in the EWG which requires students to be able to think systematically or sequentially starting from emphasizing on student personal activities to the maximum, then the results of each student's previous thoughts will be discussed again with their group colleagues and then the results of student discussions will be presented in front of the class. so that they can develop intellectual abilities as part of the mental process. As a result, students are not only required to master the course material, but how they can use their potential so that they can grow self-confidence.

The number of group members consisting of only two people also makes it easier for students with field independent cognitive styles to work together. In addition, the learning method used is the method of presentation, question and answer, and demonstration with existing media, laptops and projectors so that it is suitable for students who have an independent field of cognitive style who usually have difficulty when asked to capture an abstract lecture material and which requires strong imagination. He tends to capture lecture material that is presented verbally and which he can see. In other words, it requires many examples or demonstrations and all of these are presented in a systematic and sequential form.

On the other hand, the cognitive style according to the CTL learning model is the field dependent cognitive style. where students with field dependent cognitive style tend to have the ability to receive lessons randomly so that they become people who are full of new ideas. So there is no problem for him if learning is obtained from various groups because in CTL learning, students who act as guests every 15 minutes have to exchange positions to seek information from each group. In addition, dependent thinkers also tend to accept the type of human diversity, can contribute ideas to others and can think quickly without the help of others. So that they can work well together when they are members of the group well when they are members of the living group even though the students who are guests will continue to exchange.

From the description above, the learning model is closely connected with the student's cognitive style. Because students' cognitive style greatly affects how students solve a problem. This is in line with the opinion in addition to learning styles, learning models that need to be considered in the teaching and learning process are 
which cognitive styles are dominant in students. Each student has a different cognitive style so that the specific level of understanding is also different. The existence of this learning model can foster students' enthusiasm in learning PAK. Meanwhile, in teaching and learning activities, both the EWG and CTL learning models can take place interactively because the learning atmosphere is fun. In fact, each individual has a different cognitive style, so the learning process that occurs in them is also different. Optimal learning quality must be able to overcome these differences so that the objectives can be achieved.

\section{Conclusion}

From the results of the discussion above, several conclusions can be drawn, including:

1. The learning outcomes of Christian Religious Education students who are taught using the learning model with the EWG approach are higher than the PAK learning outcomes of students who are taught using the learning model with the CTL approach.

2. PAK learning outcomes of students who have field independent cognitive styles are higher than those of students who have field dependent cognitive styles.

3. There is an interaction between the learning model and cognitive style on students' PAK learning outcomes. In this study there was interaction because the group of students who had a field independent cognitive style got higher learning outcomes when taught with the EWG learning model compared to the group of students who were taught with the CTL learning model. On the other hand, students who have a field dependent cognitive style get higher learning outcomes when taught with the CTL learning model compared to groups of students who are taught with the EWG learning model.

\section{Bibliography}

Anthony, Michael J., 2012. Foundation of Ministry and Introduction to Christian Education for A New Generation. Malang: Gandum Mas.

Arikunto, Suharsimi. 2015. Basics of Educational Evaluation. Jakarta: Bumi Akasara

Aritonang, Jan S., 2016. Various Streams In And Around The Church. Jakarta: BPK. Gunung Mulia.

Arikunto, Suharsimi, 2016. Research Management. Jakarta: Rineka Cipta.

Baker, David L., 2015. One Bible Two Covenants. Jakaarta: BPK . Gunung Mulia

Budiyana, Hardi. 2011. Basics of Christian Religious Education. Surakarta: STT Berita Hidup.

Edlin,J. Richard. 2015. The Nature of Christian Education. Jakarta: BPK Gunung Mulia

Hamdani. 2017. Teaching and Learning Strategy. Bandung: Pustaka Setia.

Hasugian, MT., and T. Lumban Tobing. 2011. Evaluation of Christian Religious Education. Medan: Mitra

Harianto GP., 2017. PAK Theology, Methods and Application of Christian Education in the Bible. Yogyakarta; ANDI.

Harianto GP., 2012. Christian Religious Education in the Bible \& Today's World of Education. Yogyakarta: ANDI Hergenhahn, B.R. and Matthew H.O., 2014. Theories of Learning. Jakarta: Kencana Pranandamedia Group.

Jasa Ungguh M., 2016. 45 Spectacular Learning Model. Yogyakarta: AR-RUZZ MEDIA.

Kasmadi and Nia Siti Sunariah. 2016. Modern Guide to Quantitative Research. Bandung: Alfabeta.

Lase, Sudirman. 2011. Christian Religious Education for Adults. Medan: Mitra.

Lograde, Cathy. Ira Shor. 2014 Educating about social issue in the $20^{\text {th }}$ and $21^{\text {st }}$ centuries. North Carolina: Information Age Publising.

Matondang, Zulkifli. 2013. Education Statistics. Medan: Unimed Press.

Nana Sudjana. 2016. Assessment of the Results of the Teaching and Learning Process. Bandung: Remaja Rosdakarya.

Pasaribu, Andar Gunawan. 2015. Biblical Christian Religious Education Competency Application Kompetensi. Medan: Mitra

Rusman. 2017. Learning Models, Developing Teacher Professionals. Jakarta: Raja Grafindo Persada.

Rudi Susilana, and Cepi Riyana. 2017. Learning Media. Bandung: Wacana Prima

Sabdono, Eratus. 2014. My Life For You. Jakarta: Rebobot Literature

Sagala, Syaiful. 2011. Professional Ability of Teachers and Education Personnel. Bandung: Alfabeta.

Saragih, Albert. 2015. Christian Parenting (Study of Theology, Pedagogy, and Methodology) and Its Implementation in Schools. Medan: Mitra.

Sedarmayanti and Syarifuddin H., 2011. Research Methodology. Bandung: Mandar Maju.

Silitonga, SAM. 2013. Christian Religion Teaching Materials in College. Medan: Mitra.

Sudiarja, A., 2014. Education in the challenges of the times. Yogyakarta: Karnius.

Suharsaputra, Umar. 2014. Quantitative, Qualitative, and Action Research Methods. Bandung: Refika Aditama.

Sugiyono. 2017. Educational Research Methods Quantitative, Qualitative, and R\&D Approaches. Bandung: Alfabeta.

Sugiyono. 2016. Statistics for Research. Bandung: Alfabeta. 
Suyanto and Asep Jihap. 2013. Professional Teachers, Strategies to Improve Teacher Qualification and Quality in the Global Era. Jakarta: Erlangga.

Suyono \& Hariyanto. 2016. Study and Learning. Bandung: Remaja Rosdakarya.

Surya, Mohamad. 2016. Cognitive Strategies in Learning. Bandung: Alfabeta.

Sutrisno. 2011. Introduction to Innovative Learning, Based on Information and Communication Technology. Jakarta: Gaung Persada.

Smith, Donald K., 2014. Greating Understanding. Yogyakarta: ANDI.

Tambun, R. and M.T. Hasugian. 2011. Christian Religion Lamp. Medan: Mitra

Tung, Khoe Yao. 2013. Philosophy of Christian Education. Yogyakarta: ANDI.

Tung Khoe Yao. 2015. Towards Today's Dream Christian School. Yogyakarta: ANDI

Trianto. 2011. Designing Innovative-Progressive Learning Model. Jakarta: Kencana.

Verkuyl, J. 2016. General Section of Christian Ethics. Jakarta: BPK Gunung Mulia. 